INTERNATIONAL JOURNAL OF RESEARCHES IN BIOSCIENCES, AGRICULTURE AND TECHNOLOGY (C) VISHWASHANTI MULTIPURPOSE SOCIETY (Global Peace Multipurpose Society) R. No. MH-659/13(N) www.vmsindia.org

\title{
SENSORY EVALUATION OF KHOA SOLD IN BHANDARA DISTRICT
}

\author{
B. S. Wanjari, S. S. Sardare, and S. S. Asekar and G.N. Jadhav \\ Animal Husbandry and Dairy Science Section, \\ College of Agriculture, Nagpur (M.S.)
}

\begin{abstract}
:
Khoa is dehydrated whole milk product. It is traditionally prepared and marketed in Bhandara district. Total 60 samples of khoa collected from four different sources of Bhandara district. In present study sensory quality of such traditionally prepared khoa was determined by sensory evaluation for different sensory attributes by using 100 point scored card comprising of flavour (45), Body \& texture (35) and colour and appearance (20) and organoleptic evaluation for overall acceptability by a 9 point hedonic scale was developed. Result shows that the overall sensory quality score of east, west, north and south region khao were 80.67, 86.37, 87.23 and 81.23 out of 100 respectively, however total score of overall acceptability of khoa samples of north region khoa was found significantly more than other region khoa samples. So sensory quality of north region was good than east, west and south region khoa which were fair in quality.
\end{abstract}

Keywords: Khoa, Sensory quality, Sample, Acceptability

\section{Introduction:}

Milk has been used as an article of food since ancient times in India. It plays an important role in the diet. In India, the share of milk and its products is the largest after cereals, and it accounts for $16 \%$ of the total food expenditure (Mahesh kumar 2010).

India has shown impressive growth in the milk production, achieving an annual production of 132.43 MT in the year 2012-2013, while in Maharashtra annual milk production is 8.73 MT. Uttar Pradesh being the top state in milk production with $23.330 \mathrm{MT}$. India is among the world's largest and fastest growing market for milk and milk products (Anonymous 20122013). In Indian dairy sector milk production during the year 2013-2014 is estimated at 140 million tonnes (MT) as per NDDB data. (Anonymous 2013-14).

Khoa is an important indigenous milk product is used as base material for a variety of sweets such as burfi, peda, gulabjamun, milkcake, kalakand, kunda, etc. conventionally it is prepared by continuous boiling of milk in an open karahi until desired concentration (normally 65-72\% total solids) \& texture are achieved. The object of the study is to determine sensory quality of such traditionally

Prepared khoa as it is important criteria to determine shelf life and suitability of khoa for product manufacturing. There is some changes takes place in khoa during transportation, storage and overall handling due to which there is possibility of contamination, which made unfit for consumption, so it is important to check its organoleptic qualities.

\section{Material and Methods:}

The present investigation on evaluating sensory qualities of khoa samples was carried out in the laboratory of Animal Husbandry and Dairy Science section, College of Agriculture, Nagpur during year 2014-15.

Fresh Khoa samples were collected from four different sources (i.e. East, West, North and South region) of Bhandara district with stratified randomization technique and analyzed them during three different fortnights for their sensory quality. Physical quality was determined by sensory evaluation of khoa sample for different sensory attributes by a panel of 5 judges by using 100 point score card comprising of flavour (45), body and texture (35) and colour and appearance (20) suggested by $\mathrm{Pal}$ and Gupta (1985). Similarly overall acceptability determined by 9 point hedonic scale as suggested by Nelson and Trout (1964). Data generated in tabular form were statistically analyzed by using analysis of variance - two way classifications. Critical difference was calculated to study the significance.

\section{Result and Discussion:}

It is noteworthy that sensory quality of a ny product is of great significance from

consumer's acceptability point of view, since they drawn towards such products that have nice and attractive appearance. And as such it has been observed that retailers engaged in khoa marketing in the district are quite cautious and any how they were maintained its physical quality in view just to attract the consumers.

From table 1 average flavour score of khoa ranged from 36.97 to 40.73 out of 45 with maximum score contributed by north region khoa (40.73). North region khoa significantly more than other region khoa. As compared to four sources west and south khoa showed slightly inferior with rancid flavour with also burnt flavour due to more heating. Results are 
in accordance with Narain and Singh (1979), Kurand et al. (2011) and Kakade et al. (2013).

Body and texture average score of khoa ranged from 27.73 to 30.87 out of 35 with significantly maximum score contributed by north region khoa (30.87). Soft, uniform body and granular texture was observed in khoa samples of north region. From table it further seen that there was variation in average score of body and texture of khoa, with clarified the ideas of superiority of north region khoa over other regions. Findings are in close with Kulkarni and Hembade (2010), Kurand et al. (2011) and Kakade et al. (2013).

Colour and appearance score was obtained in range of 16.22 to 17.39 out of 20 . Maximum average significantly score obtained by west region khoa and being superior with creamy white colour. The samples from north and east khoa showed brownish colour while south khoa showed slightly reddish brown due to overheating and scraping with mouldy appearance. In south khoa there was presence of some amount of foreign matter hence obtained less score in respect to appearance with slightly faint sky bluish ting. Findings are in close with Kulkarni and Hembade (2010), Kurand et al. (2011), Bajaj et al. (2013) and Kakade et al. (2013).

From table 1 it was revealed that average score for overall acceptability of north region khoa is significantly more than other region khoa.

Table 1:Average Score of flavour, body \& texture, colour\& appearance, overall acceptability and organoleptic evaluation.

\begin{tabular}{|l|l|l|l|l|l|l|}
\hline $\begin{array}{l}\text { Sr. } \\
\text { No. }\end{array}$ & Region & $\begin{array}{l}\text { Flavour } \\
(45)\end{array}$ & $\begin{array}{l}\text { Body and } \\
\text { Texture } \\
(35)\end{array}$ & $\begin{array}{l}\text { Colour and } \\
\text { Appearance } \\
(20)\end{array}$ & $\begin{array}{l}\text { Overall } \\
\text { acceptability } \\
(100)\end{array}$ & $\begin{array}{l}\text { Organoleptic } \\
\text { evaluation } \\
\text { (9 point } \\
\text { Hedonic Scale) }\end{array}$ \\
\hline 1 & East & 40.35 & 30.51 & 16.25 & 87.11 & 7.13 \\
\hline 2 & West & 36.97 & 28.26 & 17.39 & 82.62 & 7.44 \\
\hline 3 & North & 40.73 & 30.87 & 16.84 & 88.44 & 8.19 \\
\hline 4 & South & 37.65 & 27.73 & 16.22 & 81.60 & 6.76 \\
\hline & S.E. $(\mathrm{m}) \pm$ & 0.42 & 0.45 & 0.16 & 0.71 & 0.054 \\
\hline & C. D. at $5 \%$ & 1.48 & 1.55 & 0.55 & 2.48 & 0.18 \\
\hline
\end{tabular}

\section{Conclusion:}

The sensory profile of khoa produced and marketed in north region of Bhandara district was better, having 87.23 overall score and shows nutty flavour. However the khoa of east, west and south region were fair in sensory quality and showed acidic and burnt flavour with hardiness texture due to overheating and more scraping and presence of visible foreign matter. North region Khoa samples have rich smell and slightly sweet taste. Such khoa is suitable for preparation of various sweets.

\section{References:}

Anonymous, 2012 - 2013. Annual Report 2012 2013, National Dairy Development Board,

Anonymous, 2012 - 2013. FAO and National Dairy Development Board website.www.fao.org/agriculture/dairy-gateway/milkproduction.

www.nddb.org/English/Statistics/pages/Milkproduction.aspx.

Anonymous, 2013 - 2014. The Hindu and The India Times news paper

article.http:/ / www.thehindu.com/business/Industry/ milkproductionrisesto140milliontonnesin2013-

14/article6085584.ece.

http://articles.economictimes.indiatimes.com/201406-26/news/_1_milk-production-national-dairy-plannddb.
Bajaj, S. J., Y. D. Deshmukh, A. L. Shirfule, K. P. Deshmukh, P. D. Satav, 2013.Quality assessment of khoa marketed in nanded city. International Journal of Green and Herbal Chemistry. Vol.2 (3): 660-664.

Kakade, N. B., V. G. Atkare, S. R. Kute, N. N. Humane, P. N. Ingle. 2013. Physico chemical study of khoa sold in Nagpur city. J. Soils and Crops. 23 (1): 111-115.

Kulkarni R.V and A.S. Hembade.2010. Sensory quality of traditionally prepared khoa in Beed district (M.S). International Research Journal. 1 (7): 10-11.

Kurand, M. S., R. R. Shelke, S. G. Gubbawar and S. P. Nage, 2011. Quality of khoa sold in washim district. Food science research Journal. 2 (2): 200204.

Maheshkumar, 2010.Up-gradation of Khoa Production and Preservation Technologies.S-JPSET. Vol. 4 (1): 37-47

Narain, N and G.S. Singh. 1981. The qualities of khoa marketed in Varanasi City. . Indian J. Dairy sci. 34 (1): 91-93.

Nelson, J. A. and G. M. Trout. 1964. Judging dairy product $4^{\text {th }} \mathrm{Adn}$. The olesen publishing Co. Milwankee official method of analysis chemist.Washigton.

Pal, D., and S. K. Gupta, 1985.Sensory evaluation of Indian milk products.Indian Dairyman. 37 (10): 465467. 